\title{
The Effectiveness of Using Mobile Learning Techniques to Improve Learning Outcomes in Higher Education
}

\author{
https://doi.org/10.3991/ijim.v14i08.13125 \\ Hosam F. El-Sofany ( $(\varpi)$ \\ King Khalid University, Abha, Kingdom of Saudi Arabia \\ Cairo Higher Institute of Engineering, Computer Science and Management,Cairo, Egypt \\ helsofanyakku.edu.sa \\ Nahla El-Haggar \\ Imam Abdulrahman Bin Faisal University, Dammam, Saudi Arabia
}

\begin{abstract}
Recently Mobile technology is considered an effective way to improve students' skills such as positive thinking, collaborative, communication, as well as it is considered the main part of major innovation in many e-learning research areas. As a result of the 21 st. century requirements, skills were developed to address the rising needs in higher education which causes a shifting paradigm from the traditional methods of teaching to M-learning. In this research, we discuss the effect of using Mobile learning techniques to improve learning outcomes in Higher Education. We have implemented a web-based survey through two questionnaires. The questionnaires were distributed among $200 \mathrm{stu}-$ dents in the second and third levels in the computer science department at both Community College and College of Arts and Science. This research explores a study on e-learning using mobile technology to identify students' perceptions in the acceptance of mobile techniques and recognize the quality of mobile services for academic and social purposes to improve teaching strategy and learning performance in higher educational organizations. The outcomes of this research would support the evolution of M-learning at the university-level and cause shifting the traditional learning methods by merging M-learning methodologies as a learning management system that provides mobile learning services to students and teachers any time and from any location. The research study shows some important results towards the integration of mobile technology into teaching include: student positive perception, facilitates student concentrate, flexible access to m-services for learning materials, and increases students' skills in using mobile technology for e-learning.
\end{abstract}

Keywords-E-learning, M-learning, learning outcomes, teaching tools, Higher Education

\section{Introduction}

Originally the educational environment begins with traditional learning, where students are required to attend the classes. The other way round, distance learning was 
used where students could use videos and books to study abroad. Later the computer embedded in the educational strategy, the learning materials were presented through computers which are called online learning [1]. In $21^{\text {st. }}$ century information and communication technology have become an essential section of the teaching process by changing all aspects of education to improve a lecturer's pedagogical practices and promote effective ways to manage time in the classroom [2]. In the late 80s, E-learning emerged as a new way of technologies in modern education and training systems.

The recent learning management systems (LMS) environment of E-learning that accessed using wireless devices (such as, mobile phones, smart mobile phones, Apple's iPods, or tablet PCs, etc.) is called M-learning. The applications of these devices are integrated with the $\mathrm{Wi}-\mathrm{Fi}, 4 \mathrm{G}$, and $5 \mathrm{G}$ telecommunication networks which are mainly based on wireless technologies usage which allows students to access learning resources include lectures, assignments, quizzes and collaborate or support activities in fieldwork without any restrictions on time and location. [3, 4]. Mobile devices help students to co-operate with their peers in programs, social media for email, online messaging, blogging, and various social networking sites, that allowing students to progress their programs by gaining credits [5, 6]. M-learning, as a new model, promotes elasticity; for which students don't need to be in a specific age or having specific skills to participate in learning approaches [7]. The main objectives of this research include, (1) identifying students' perceptions in the acceptance of mobile techniques and recognize the quality of mobile services for academic and social purposes to improve learning in higher educational institutions, (2) determining students' level skills in technological literacy [8].

This paper is organized as follows: Section 2 represents the literature review of the effect of M-learning and the sharing of knowledge between students in higher education institutions (HEIs). Section 3 introduces some comparisons between the E-learning and M-learning. Section 4 illustrates the M-services and teaching tools in HEIs. Section 5 introduces a quantitative research methodology for detecting the students' feedback on the acceptance of mobile technology and evaluate the quality of mobile services for academic and social purposes, as well as for determining the students' level skill in technological literacy. Section 6 presents the results and discussion. The paper is concluded in Section 7.

\section{Related Work}

Sharples, (2000) [9] suggested a scheme for M-learning through the incorporation of hardware, software and mobile technology into the learning process to improve the interaction between students and their teachers by increasing the physical distance between them, since M-learning is a technology of any time anywhere. Furthermore, Park (2011) [10] indicated that M-learning is capable of improving traditional learning through effective applications that facilitate interaction in a formal learning environment to allow interactive learning resources in a conducive virtual environment for life- 
long learning. Chen et al. (2008) [11] pointed out the importance of studying the perceptions of students and their requirements for using M-learning to help the decisionmaker adoption of mobile learning successfully in the university-level environment.

Kothamasu (2010) [12] presented that mobile learning is not just learning through wireless devices, but mobile phones can provision several emergence services such as SMS, MMS, Email, etc. The authors show that, in addition to mobile communications, available. Alzaza and Yaakub, (2011) [13] explore the importance of using M-learning services for university-level students in Malaysia. The outcomes demonstrated that the course enrollment and exam results are the greatest services' rate followed by library, schedule, and admission services. Research by Adeyeye et al. (2013) [14] presented that there are many factors affect the success or fails of mobile learning-based projects. These factors are based on software accessibility, institutional support, network connectivity, study curriculum capability, student experiences, and the technology owned by the students. According to Behera (2013) [15] and Sa'nchez-Prieto et al. (2016) [16], M-learning is included in E-learning, but it is a separate approach, as M-learning performance can be implemented based on understanding the challenges and opportunities of mobile devices. Mohanna (2015) [17] presented the possibility of integration among M-learning, software and hardware technologies to create multimedia applications capable of facilitating the interaction of educational content in various formats such as lectures, quizzes, tutorials, games, short messages, and multimedia. As an attempt to explore the use of M-learning in universities, Andrew and others (2017) [18] addressed classes of ways, including promoting on-campus interactivity through mobile devices, a student needs an inquiry, and low-cost M-learning approaches. Deemah A. Al-Arabiat, (2018) [19] examines the effect of M-learning and the sharing of knowledge between students at the university level. The outcome of the research presented that, mobile learning technical barriers have a negative effect on M-learning and the growth of cloud computing will expand incentives to address M-learning's technical problems.

\section{$3 \quad$ E-learning and M-learning}

E-learning includes the use of computers, wireless devices, and video conferences through the internet, not only for content delivery but also for interaction among students. M-learning is considered as an extended generation of E-learning supported by wireless devices [20]. The main feature and benefit of M-learning are that it isn't limited to a specific place, such as sitting in a classroom or in front of a computer. Students can use M-learning anywhere and anytime as well as teachers, can provide students with materials and resources anywhere anytime they want (see Figure 1). This concept gives the learner the new freedom for learning, it also increases the flexibility of teachers, who can develop (on-the-spot) learning materials to meet specific needs or provide direct feedback and support to students. The M-learning concept can be classified into three main classes include mobility of learning, mobility of the learner, and mobility of technology as shown in Table I [21]. 


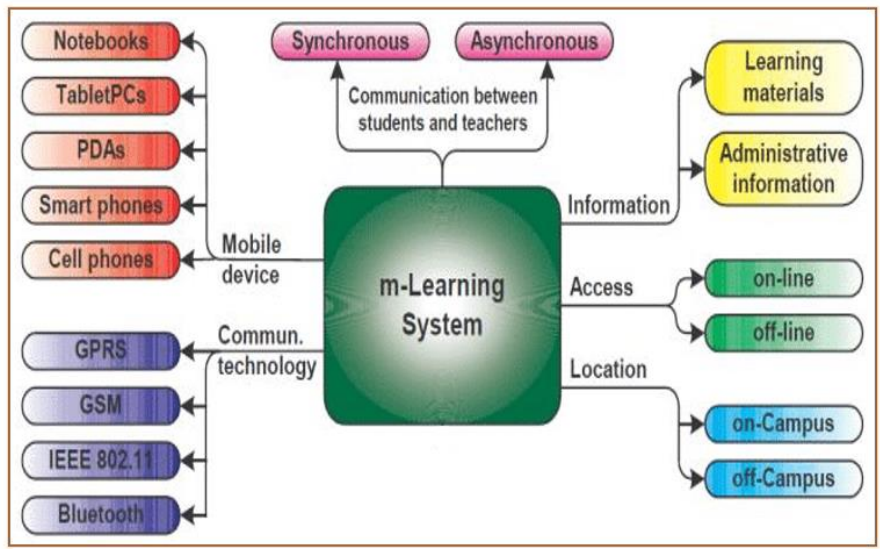

Fig. 1. M-learning system classification

Table 1. M-learning classification and features

\begin{tabular}{|l|l|}
\hline M-Learning Classes & \multicolumn{1}{|c|}{ Features } \\
\hline Mobility of technology & $\begin{array}{l}\text { The ability to use portable digital devices to deliver educational materials to all } \\
\text { participants based on wireless application protocols (WAP) and wireless fidelity } \\
\text { (Wi-Fi). Also, they have many services such as Email, SMS, MMS, etc. }\end{array}$ \\
\hline Mobility of Learner & $\begin{array}{l}\text { The ability to learn and communicate with other learners everywhere and anytime } \\
\text { through a specific delivery channel. }\end{array}$ \\
\hline Mobility of Learning & $\begin{array}{l}\text { The ability to transmit all different educational materials of higher educational } \\
\text { learning via mobile phones. }\end{array}$ \\
\hline
\end{tabular}

\subsection{Comparison between E-learning and M-learning}

Both E-learning and M-learning models have some differences among them as shown in Table II and have common features between them as follows [22]:

1. The two models are student centered, teaching, learning process (i.e., self-learning).

2. Students can access and explore the Internet by electronic devices such as computers, mobiles, PDA, etc.

3. Provide interaction between participants in the educational process: students, tutors, and institutions.

4. Provide learning opportunities for many students.

5. Deliver educational materials in different ways such as texts, images, and video clips.

6. Enable automatic attendance for a student without entering the classroom actually.

7. The two models include infrastructure and a broad community-based approach to wired and wireless devices technologies. 
Table 2. Comparison between some feature of E-learning and M-learning

\begin{tabular}{|l|l|l|}
\hline \multicolumn{1}{|c|}{ Feature } & \multicolumn{1}{|c|}{ E-Learning } & \multicolumn{1}{c|}{ M-Learning } \\
\hline Devices & PCs, laptops & Smart Phone, PDA and Tablet \\
\hline Structure & $\begin{array}{l}\text { Structured, formal and time-bound } \\
\text { format of teaching. }\end{array}$ & $\begin{array}{l}\text { Unstructured, on-demand, timely and } \\
\text { context-aware form of education dissemination. }\end{array}$ \\
\hline Network & Wired and Bandwidth & Wireless, GPRS, Bluetooth, 4G, and 4GLET \\
\hline Protocol & Web-Based & WAP-Based \\
\hline Accessibility & Private location & No geographical location \\
\hline Connectivity & Intranet or Internet & $\begin{array}{l}\text { Mobile Networks, GSM, GPRS, UMTS, and } \\
\text { CDMA. }\end{array}$ \\
\hline $\begin{array}{l}\text { Communication pro- } \\
\text { tection }\end{array}$ & $\begin{array}{l}\text { low levels of protection because of } \\
\text { using multiple devices }\end{array}$ & $\begin{array}{l}\text { More protection because of using personal } \\
\text { devices }\end{array}$ \\
\hline $\begin{array}{l}\text { Instructor to Student } \\
\text { communication }\end{array}$ & $\begin{array}{l}\text { Asynchronous Delayed (E-mail) } \\
\text { Interactive }\end{array}$ & $\begin{array}{l}\text { Synchronous Instant message \& MMS } \\
\text { Spontaneous }\end{array}$ \\
\hline Usability & $\begin{array}{l}\text { Difficult to transfer books and files } \\
\text { between individuals. }\end{array}$ & $\begin{array}{l}\text { easy to exchange books and files between } \\
\text { learners by Bluetooth and IR technologies }\end{array}$ \\
\hline Learning process & Simulated Situation & Social Interaction \\
\hline
\end{tabular}

\section{$4 \quad$ M-services and Teaching Tools in Higher Education}

With the exponential growth of technology particularly in both mobile devices and wireless networks. The main objective of Higher Education Institutions (HEIs) attempt to improve learning outcomes and enhance the academic performance of the students by integrating students with M-learning. So, HEIs are allowing M-learning services based on different teaching technological tools to develop their services. Among these tools Social networks, Web-based platforms, internet of things (IoT) [23].

\subsection{M-learning services}

In this paper, we have classified M-learning services into two categories based on learning materials and administrative information services [24]:

Learning materials services: These services based on the contents of student courses that allow students to:

- Access to course material

- Access continuously the course content and online presentation

- The ability to access the coursework tools (assignments, quizzes, announcements, timetables, user management, and etc.)

Administrative services: Administrative information services of M-learning allow students to [24]:

- Automatic evaluation of teaching system.

- Provide the opportunity of taking external and internal exams.

- Admission services and course registrations.

- Automated library services 
- Provide a discussion of new ideas and suggestions for addressing teaching and research issues.

- Encourage comprehensive learning delivery.

- The achievement of all learning phases and control the students learning outcomes.

- Create a universal educational and research environment, etc.

\subsection{Educational tools based on M-devices}

Teaching tools based on mobile technologies include Social networks, Web-based platforms, and the Internet of Things (IoT), that support activities of teachers to introduce advanced and effective ways of learning [25].

\subsection{Social network tools}

Social networks allow academic staff to share knowledge among students. Also, enables them to interact with other teachers at other locations to get different perspectives on learning, and teaching $[45,46]$. Social network tools for teaching are introduced in Table III, these tools enable students to collaborate in learning and improve their skills, and collaboration. As a result, social networks develop students' performance and motivation for learning [26].

\subsection{Web-based platforms}

Table III presented some web-based platforms that support teachers in their teaching activities to mentor the students and adoptive a comprehensive learning process with many attractive courses [27]. 
Table 3. Teaching Tools Based on Mobile Technologies

\begin{tabular}{|c|c|c|c|}
\hline $\begin{array}{l}\text { Educational } \\
\text { technology tools }\end{array}$ & Type & Tools & Benefits \\
\hline Leaming tool & Mobile devices & $\begin{array}{l}\text { mobile phone, PDA, } \\
\text { smart phone, } \\
\text { (Apple's iPod), or } \\
\text { tablet }\end{array}$ & $\begin{array}{l}\text { 1- Facilitate of innovative leaming activities. } \\
\text { 2- support the process of knowledge acquisition } \\
\text { 3- Develop communication, problem-solving, } \\
\text { creativity and a variety of high-level skills in } \\
\text { students. } \\
\text { 4- Enhance the student's motivation to leam. }\end{array}$ \\
\hline \multirow{10}{*}{ Teaching tools } & \multirow{4}{*}{ Social networks } & Facebook & $\begin{array}{l}\text { 1- engage students in leaming and helps them } \\
\text { develop skills in creativity, collaboration and } \\
\text { communication }\end{array}$ \\
\hline & & Twitter & $\begin{array}{l}\text { 2-improve students' performance, motivation for } \\
\text { leaming. }\end{array}$ \\
\hline & & Blogs & $\begin{array}{l}\text { 3- Blogs are used for collaborative learning. } \\
\text { students can publish their course projects and } \\
\text { assignments and also explore the work of others. }\end{array}$ \\
\hline & & YouTube EDU & $\begin{array}{l}\text { 4- YouTube EDU, it offers educational videos } \\
\text { developed by diverse institutions. Teachers are } \\
\text { able to adapt these videos to their particular needs }\end{array}$ \\
\hline & \multirow{3}{*}{ Web-based platforms } & $\begin{array}{l}\text { Rapid Cycle } \\
\text { Evaluation Coach }\end{array}$ & $\begin{array}{l}\text { 1- Depending on the platform, these tools can } \\
\text { support effectively the new role of professors as } \\
\text { mentors of students. }\end{array}$ \\
\hline & & TED-Ed & $\begin{array}{l}\text { 2- Teachers can offer a more convenient form of } \\
\text { teaching that considers the needs of students. }\end{array}$ \\
\hline & & $\begin{array}{l}\text { Curatr } \\
\text { Moodle }\end{array}$ & $\begin{array}{l}\text { 3- help teachers to foster a deeper leaming } \\
\text { process with more engaging courses }\end{array}$ \\
\hline & \multirow{3}{*}{$\begin{array}{l}\text { Intemet of Things } \\
\text { (IoT) }\end{array}$} & $\begin{array}{l}\text { Smart classroom } \\
\text { environment devices }\end{array}$ & $\begin{array}{l}\text { 1- Facilitates interactions among students and } \\
\text { teachers and can accelerate the understanding of } \\
\text { concepts. }\end{array}$ \\
\hline & & Attendance systems & $\begin{array}{l}\text { 2- improve the quality of education and } \\
\text { satisfaction of students }\end{array}$ \\
\hline & & $\begin{array}{l}\text { Real-time feedback } \\
\text { on lecture quality }\end{array}$ & $\begin{array}{l}\text { 3- Sensing and monitoring technology used to } \\
\text { determine student reaction to a lecture. Real time } \\
\text { feedback is provided in order for professors to } \\
\text { modify the dynamics of the class opportunely }\end{array}$ \\
\hline
\end{tabular}

\subsection{Internet of Things (IoT)}

"Things" refers to any equipment, servers, devices, etc., that are connected to the internet and used as independent tools that making teaching activities more efficient and attractive. Sensing and monitoring technologies are used to assess student responses to a lecture. Real-time feedback is given to allow teachers to adjust the class dynamics in a timely manner. Table III shows the M-learning types involved in the IoT tools for learning environments. These tools facilitate interactions among students and teachers and improve the outcomes of education [28-30].

\section{$5 \quad$ Methodology}

The aims of this research are to detect the students' feedback on the acceptance of mobile technology to the development process which possibly could enhance learning process to meet students' requirements and evaluate the quality of mobile services for academic and social purposes, as well as for determining the students' 
level skill in using recent technological tools. A quantitative research methodology was used to achieve these proposes.

\subsection{Instrument, participants, and data collection}

In this research, we have used a quantitative methodology and an instrument (questionnaire) to gather the necessary data. An assessment sheet was prepared which contains 26 questions. The questionnaire is composite into three parts:

In the first part, the study used a 5-point Likert scale ranging from SD (Strongly Disagree), D (Disagree), N (Neutral), A (Agree), SA (Strongly Agree) to explore the students' satisfaction towards applying M-learning. In the second part, the study used flexibility scales ranging from 1 to 3, where 1- Strong Flexible, 2- Moderate Flexible and 3-Poor Flexible to explore the use of M-devices to improve student M-learning process because of their ability to facilitate access to the educational tools. Finally, in the third part, the study used scales ranging from HS=High Skilled, MS= Moderately Skilled and PS= Poorly Skilled to investigate the level of technological literacy skills of the students.

Two questionnaires were distributed among 200 students in the second and third levels in the Computer Department at Community College at Dammam, Imam Abdulrahman Bin Faisal University, and College of Arts and Science at King Khalid University, KSA.

Data were collected for two semesters of the 2018/2019 academic year. Questionnaires were retrieved and the successful questionnaires were chosen according to the following factors:

1. The respondents have used M-learning,

2. All questions have answered by the students

3. There are no inconsistent answers.

\section{$6 \quad$ Results and Discussion}

The percentage for each question was determined using the following equation, out of a total of 200 students who answered the questionnaire.

$$
S_{i} \%=\frac{\text { frequancy of answerw in each scale }}{\sum \text { frequancy of answerw in all scales }} * 100
$$

Where $i$ is the number of questions from 1-26.

\subsection{The satisfaction of M-learning as learning tools}

Table IV shows the results of the questionnaire's statements regarding the factors affecting the satisfaction of M-learning as learning tools between respondents. There are 8 statements, and the mean score for each statement was used to describe the strength of each one. In this experiment, the highest mean score is "I am satisfied with 
the M-learning resources" $(\mathrm{M}=4.65)$. The second highest mean score is "M-learning offers continues interaction" $(\mathrm{M}=4.525)$, followed by "M-learning improves my skills acquisition" ( $M=4.445)$ and "M-learning optimize the use of learning time" $(\mathrm{M}=$ 4.245). The lowest mean score is "M-learning very convenient to use in the future" $(M=$ 3.99). The second-lowest mean score "is-learning Improves my ability to study" ( $\mathrm{M}=$ 3.93). Figure 2 displays the results of the satisfaction of M-learning as learning tools.

Table 4. Satisfaction of M-learning as learning tools

\begin{tabular}{|l|c|c|c|c|c|c|}
\hline \multicolumn{1}{|c|}{ Statement } & SD \% & D \% & N \% & A \% & SA \% & M \\
\hline S1. I am satisfied with the m- learning resources & 1.5 & 2.5 & 5 & 11.5 & 79.5 & 4.65 \\
\hline S2. Improves my skills acquisition & 4 & 2.5 & 8.5 & 15 & 70 & 4.45 \\
\hline S3. Optimizes the use of learning time & 6.5 & 7.5 & 8.5 & 10 & 67.5 & 4.25 \\
\hline S4. Improves my ability to study & 4.5 & 4 & 22.5 & 32 & 37 & 3.93 \\
\hline S5. Offers continues interaction & 1.5 & 4 & 6.5 & 16.5 & 71.5 & 4.53 \\
\hline S6. learning easier to review lessons anytime & 4 & 5.5 & 4.5 & 12.5 & 73.5 & 4.34 \\
\hline S7. Very convenient to use in the future & 3 & 5 & 16.5 & 41 & 34.5 & 3.99 \\
\hline S8. learning is exciting and engaging & 14 & 10 & 17 & 32.5 & 26.5 & 3.48 \\
\hline
\end{tabular}

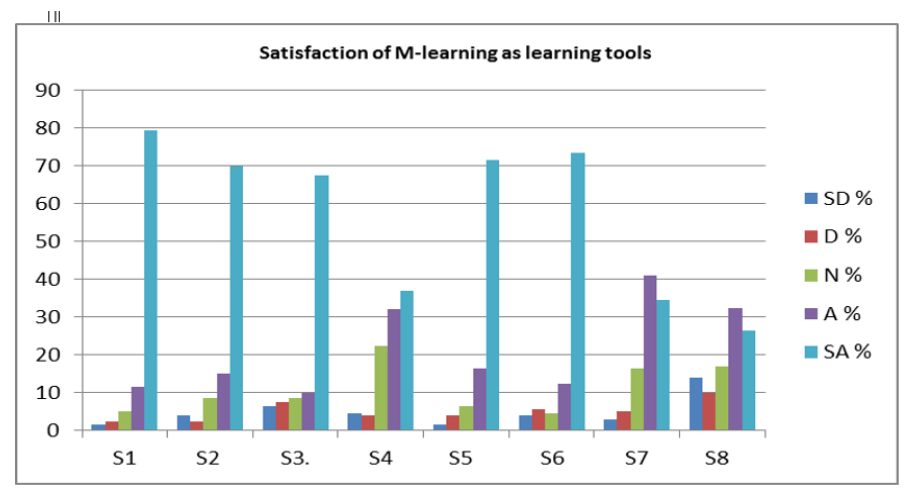

Fig. 2. Satisfaction of M-learning as learning tools

\subsection{Students' perceptions towards flexibility to access M-services}

The experiment depends on scales 1: 3; where 1 is Flexible, 2 is Neutral and 3 is Not Flexible, to reveal the students' perceptions on m-learning services to enhanced students due to its capabilities in facilitating accessing learning tools. Table 5 illustrates the results of the two main types of M-learning services depending on the information. There are 4 statements for assessing the flexibility of learning materials services and 7 statements for administrative services based on mobile devices.

\subsection{Learning materials services}

The research suggested that out of the 200 respondents, $95 \%$ of the respondents have used their mobile devices for accessing the course material, and coursework (such as 
course PowerPoint presentations, assignments, quizzes, etc.) whenever and wherever they go, $97 \%$ of students demonstrated that they have a strong flexible by using their mobile phones to access the schedule services and retrieving exam results during specific periods. In addition, $81 \%$ of the students found that it was strongly flexible to the use of M-learning to improve their academic performance and facilitate self-learning, while $87 \%$ of the respondents M-learning is designed to support knowledge reveals that great flexibility for M-learning to support knowledge sharing, dynamic learning activities and collaboration among students and professors through mobile devices. Figure 3 illustrates the flexibility to access M-services.

\subsection{Administrative services}

This study depicted that the participants confirmed have strong flexibility by using their mobile devices, $75 \%$ for automatic evaluation of lectures and professors, $86 \%$ for providing a chance of taking external and internal exams. $81 \%$ in admission services and course registrations. $60 \%$ to access library services, $70 \%$ a quick discussion of evolving ideas to manipulate teaching and research tasks. $90 \%$ for supporting different learning levels, assignments, and control the achievement of students learning outcomes. $76 \%$ for allowing merging among research and educational information environment. Figure 4 represents the flexibility of administrative M-services.

Table 5. Students' perceptions about flexibility to access M-services

\begin{tabular}{|c|c|c|c|}
\hline Statement & Strong & $\begin{array}{l}\text { Mod- } \\
\text { erate }\end{array}$ & Poor \\
\hline Learning materials services & \multicolumn{3}{|c|}{ Flexibility } \\
\hline S9. Allowing continuous access of course material, and coursework functions & $95 \%$ & $3 \%$ & $2 \%$ \\
\hline $\begin{array}{l}\text { S10 Enabling scheduled services and checking examination results during specific } \\
\text { periods }\end{array}$ & $97 \%$ & $2 \%$ & $1 \%$ \\
\hline S11. Improving academic achievement and enable them to independent learning. & $81 \%$ & $15 \%$ & $4 \%$ \\
\hline $\begin{array}{l}\text { S12. Enabling knowledge sharing, dynamic learning activities and collaborative } \\
\text { among students and Professors }\end{array}$ & $87 \%$ & $11 \%$ & $2 \%$ \\
\hline \multicolumn{4}{|l|}{ Administrative services } \\
\hline S13. Enabling evaluation of lectures and professors & $75 \%$ & $21 \%$ & $4 \%$ \\
\hline S14.Providing an opportunity of conducting external and internal exams. & $86 \%$ & $10 \%$ & $4 \%$ \\
\hline S15. Facilitating admission services and course registrations & $81 \%$ & $14 \%$ & $5 \%$ \\
\hline S16. Facilitating to access library services & $60 \%$ & $21 \%$ & $19 \%$ \\
\hline $\begin{array}{l}\text { S17. A prompt discussion of emerging ideas to address teaching and research } \\
\text { tasks. }\end{array}$ & $70 \%$ & $18 \%$ & $12 \%$ \\
\hline $\begin{array}{l}\text { S18. Enable all stages of learning, gathering assignments, monitoring and control } \\
\text { the achievement of students learning outcomes. }\end{array}$ & $90 \%$ & $7 \%$ & $3 \%$ \\
\hline S19. Permitting integration of research and educational information environment & $76 \%$ & $10 \%$ & $14 \%$ \\
\hline
\end{tabular}




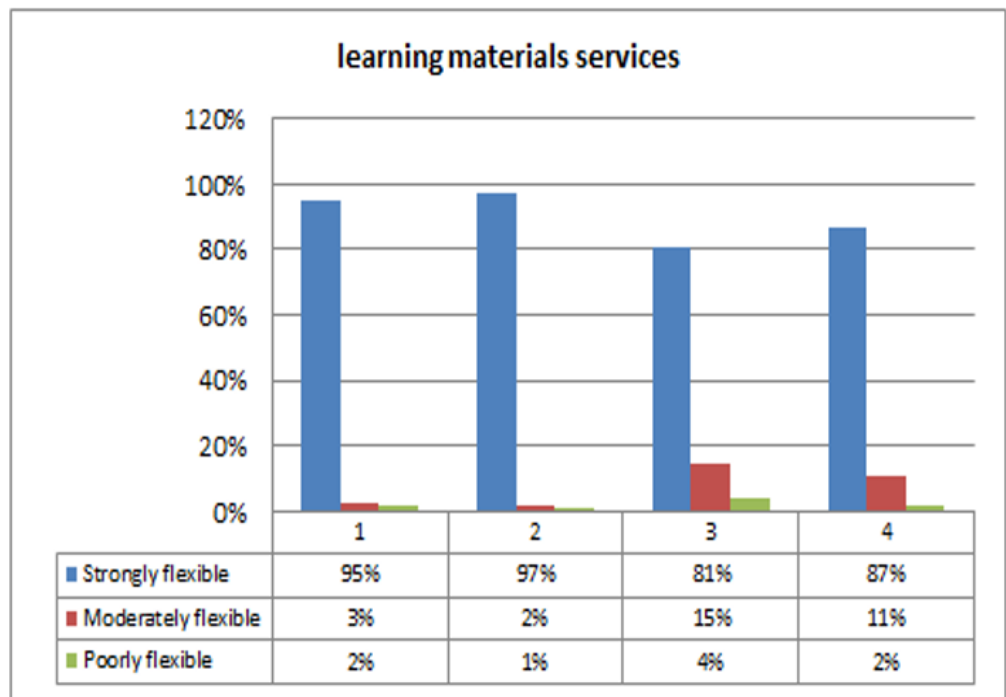

Fig. 3. Flexibility to access M-services

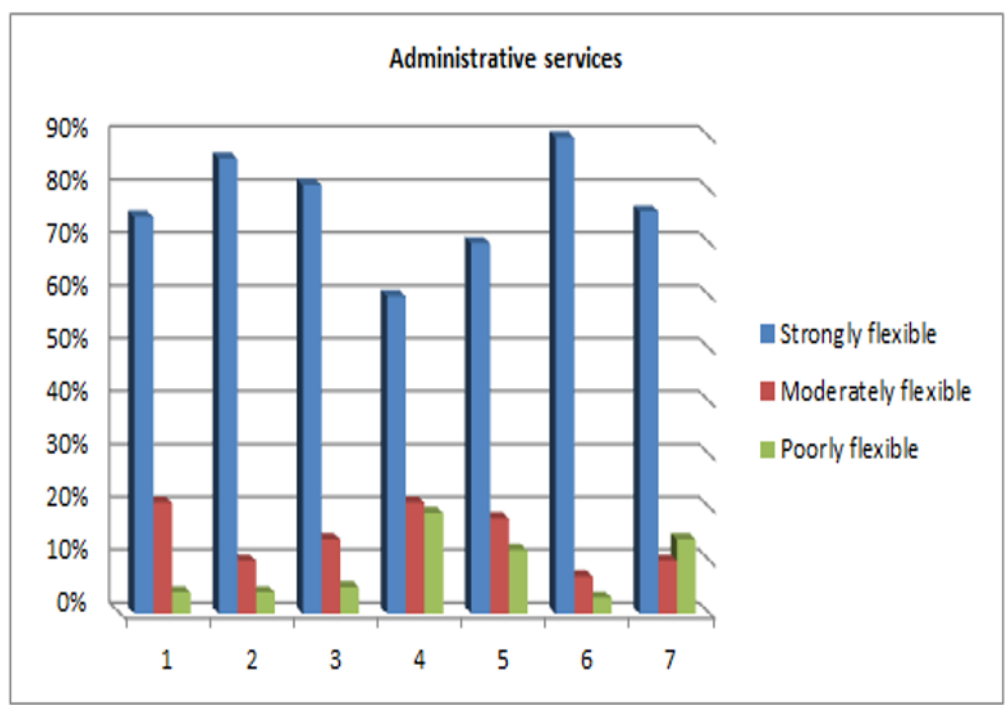

Fig. 4. Flexibility to administrative M-services

\subsection{Students' level skills in technological literacy}

In this research, the authors used three scales ranging from 1- Highly skilled, 2Moderately skilled and 3- Poorly skilled to determine the level of students' skills in technological literacy. The respondents rated themselves "Highly skilled" in using Mlearning at the universities that help for changing traditional learning methods 
by merging M-learning methodologies. Table 6 shows the results of the proposed experiments. The research establishes that the majority of respondents $97 \%$, "very skilled" in chatting through different social media, 92.9\% YouTube, VOIP (streaming Tech), $91 \%$ M-device expertise, $86 \%$ in sending email and receiving massage, $84 \%$ were very skilled in Downloading apps and /or Reading of e-books. $80 \%$ in research for data and information and the lowest rank was $65 \%$ to cooperate with others through Video Conferencing. The experimental results of this research are shown in Figure 5.

Table 6. Level of students' skills in technological literacy

\begin{tabular}{|l|c|c|c|}
\hline \multicolumn{1}{|c|}{ Statement } & \multicolumn{2}{c|}{ Skilled } \\
\cline { 2 - 4 } & Highly & Moderately & Poorly \\
\hline S20. M-device expertise & $91 \%$ & $7 \%$ & $2 \%$ \\
\hline S21. Chatting using social media & $97 \%$ & $2 \%$ & $1 \%$ \\
\hline S22.Sending e-mails and receiving massages & $86 \%$ & $13 \%$ & $1 \%$ \\
\hline S23. YouTube, VOIP (streaming Tech) & $92 \%$ & $7 \%$ & $1 \%$ \\
\hline S24. Video Conferencing & $65 \%$ & $17 \%$ & $18 \%$ \\
\hline S25. Downloading apps and /or Reading of e- books & $84 \%$ & $10 \%$ & $6 \%$ \\
\hline S26. Researching & $80 \%$ & $9 \%$ & $11 \%$ \\
\hline
\end{tabular}

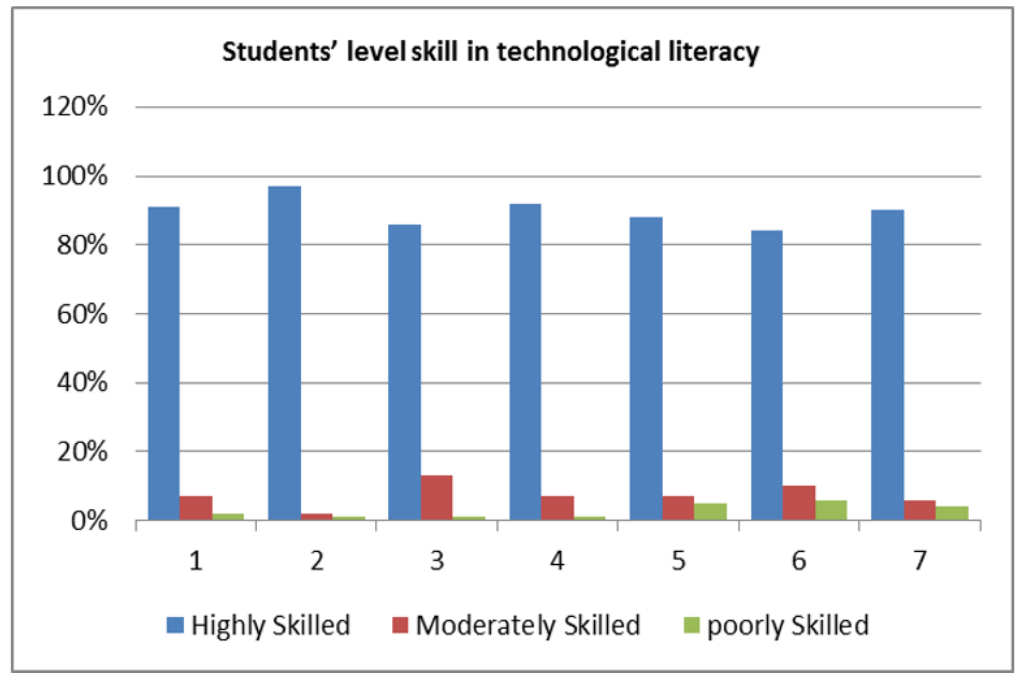

Fig. 5. Level of students' skills in technological literacy

\section{Conclusion}

This research introduced a study on E-learning using mobile technology and identified students' perceptions in the acceptance of mobile techniques and the quality of mobile services for academic and social purposes to improve teaching and learning performance and outcomes in higher educational institutions. The research study conducted at both Imam Abdulrahman Bin-Faisal, and King Khalid universities. A total 
of 200 undergraduate students from two universities have participated in the research study. The outcomes of this study supported the development of Mlearning at the universities and help for changing traditional learning methods by merging M-learning methodologies as a learning management system that provides mobile learning services to students and teachers at any time and from any location. The research study has shown some important results towards the integration of mobile technology into teaching include: student positive perception, facilitates student concentrate, access flexibility to m-services for learning materials, and increase student' skills in using mobile technology for e-learning.

\section{Acknowledgement}

The authors extend their appreciation to the Deanship of Scientific Research at King Khalid University for funding this work through General Research Project under grant number (GRP-35-40 /2019).

\section{$9 \quad$ References}

[1] Bayan Abu Shawar. 2017. Neither Completely M- Nor E-Learning: Integrating both is the Solution. In Proceedings of the 2017 International Conference on Cloud and Big Data Computing (ICCBDC 2017). ACM, New York, NY, USA, 112-118. https://doi.org/10. $1145 / 3141128.3141144$

[2] Muhammad Anshari, Mohammad Nabil Almunawar, Masitah Shahrill, Danang Kuncoro Wicaksono, Miftachul Huda,"Smartphone usage in the classrooms: Learning aid or interference?". Education and Information Technologies Volume 22 Number 6. Springer Science+Business Media New York 2017. https://doi.org/10.1007/s10639-017-9572-7

[3] Mobile learning for teachers in Europe: exploring the potential of mobile technologies to support teachers and improve practice. Paris: UNESCO, 2012.

[4] Muhammad Anshari, Mohammad Nabil Almunawar, Masitah Shahrill, Danang Kuncoro Wicaksono, Miftachul Huda,"Smartphone usage in the classrooms: Learning aid or interference?". Education and Information Technologies Volume 22 Number 6. Springer Science+Business Media New York 2017. https://doi.org/10.1007/s10639-017-9572-7

[5] Buchholz, A., Perry, B., Weiss, L. B., \& Cooley, D. (2016). Smartphone use and perceptions among medical students and practicing physicians. Journal of Mobile Technology in Medicine, 5(1), 27-32. https://doi.org/10.7309/jmtm.5.1.5

[6] Clark, E. Digital Transformation: What Is It? EDUCAUSE Review https ://er.educa use.edu/artic les/2018/5/digit al-trans forma tion-what-is-it?utm_sourc e=Infor mz\&utm_mediu m=Email \&utm_campa ign=ER\#_zs4eO ng1_zlwqD r4 (2018). Accessed 31 May 2018.

[7] Boyle, A. M., \& O’Sullivan, L. F. (2016). Staying connected: Computer-mediated and faceto-face communication in college students' dating relationships. Cyberpsychology, Behavior and Social Networking, 19(5), 299-307. https://doi.org/10.1089/cyber.2015.0293

[8] Heflin, H., Shewmaker, J. and Nguyen, J. 2017. Impact of mobile technology on student attitudes, engagement, and learning. Computers \& Education, 107, 91-99. https://doi.org/10. $\underline{1016 / j . c o m p e d u .2017 .01 .006}$ 
[9] Sharples, M. (2000). The Design of Personal Mobile Technologies for Lifelong Learning. Computers and Education, 34(177-193). https://doi.org/10.1016/s0360-1315(99)00044-5

[10] Park, Y. 2011. " A Pedagogical Framework for Mobile Learning: Categorizing Educational Applications of Mobile Technologies into Four Types". International Review of Research in Open and Distance Learning Vol. 12.2 February. https://doi.org/10.19173/irrodl.v12i2.791

[11] Chen, C. M., \& Chung, C. J. (2008). Personalized mobile English vocabulary learning system based on item response theory and learning memory cycle. Computers \& Education, 51(2), 624-645. https://doi.org/10.1016/j.compedu.2007.06.011

[12] Kothamasu KK (2010) Odl Programmes Through M-learning Technology. Retrieved from http://oasis.col.org/bitstream/handle/11599/2214/2010 KothamasuK ODLProgrammes.pdf?.

[13] Alzaza, N. S., \& Yaakub, A. R. (2011). Students' awareness and requirements of mobile learning services in the higher education environment. American Journal of Economics and Business Administration, 3(1), 95. https://doi.org/10.3844/ajebasp.2011.95.100

[14] Adeyeye MO, Musa AG, Botha A, et al. (2013) Problem with multi-video format M-learning applications. In J. E. Pelet (Eds.), E-Learning 2.0 Technologies and Web Applications in Higher Education (Chapter 10), Oman: IGI Global. https://doi.org/10.4018/978-1-46668789-9.ch032

[15] Behera SK (2013) E- and M-learning: A comparative study. International Journal on New Trends in Education and Their Implications 4(3): 65-78.

[16] Sa'nchez-Prieto JC, Olmos-Miguelanez S and Garca-Penalvo FJ (2016) Informal tools in formal contexts: Development of a model to assess the acceptance of mobile technologies among teachers. Computers in Human Behavior 55(Part A): 519-528. https://doi.org/10. 1016/j.chb.2015.07.002

[17] Mohanna M (2015) Using knowledge engineering for modeling mobile learning systems. Doctoral Dissertation, Universite' Laval, Canada.

[18] Andrew Litchfield, Laurel Evelyn Dyson and Elaine Lawrence, Agnieszka Zmijewska "Directions for M-learning research to enhance active learning," in Ascilite Singapore 2007.

[19] Deemah A. Al-Arabiat, Wan Fatimah Wan Ahmad and Aliza Sarlan, "Mobile Learning and Software as a Service: The Effect on Knowledge Sharing". 2018 4th International Conference on Computer and Information Sciences (ICCOINS). https://doi.org/10.1109/iccoins.2018.8510616

[20] Sujit Kumar Basak, Marguerite Wotto and Paul Be'langer", E-learning, M-learning, and Dlearning: Conceptual definition and comparative analysis ".E-Learning and Digital Media 2018, Vol. 15(4) 191-216, 2018. https://doi.org/10.1177/2042753018785180

[21] Ligi B, Dr B. William Dharma Raja," MOBILE LEARNING IN HIGHER EDUCATION". International Journal of Research - GRANTHAALAYAH Vol.5 (Iss.4: SE): April 2017.

[22] R. Kaliisa, M. Picard, "A systematic review on mobile learning in higher education: The African perspective," The Turkish Online Journal of Educational Technology, vol. 16, no. 1, pp.1-18, 2017.

[23] Marcela Hernandez-de-Menendez,Ruben Morales-Menendez1"Technological innovations, and practices in engineering education: a review". International Journal on Interactive Design and Manufacturing (IJIDeM) 2019 @ S Springer-Verlag France SAS, part of Springer Nature 2019. https://doi.org/10.1007/s12008-019-00550-1

[24] C. Povah and S. Vaukins. Generation Z is starting university - but is higher education ready? Retrieved January 5, 2018. from https://www.theguardian.com/higher-educationnetwork/2017/jul/10/generation-z-starting-university-highereducation-ready (19.12.2017.) 
[25] Olga Guchinskaya, Larisa Kraeva, "From the E-Learning and Blended-Learning to M-learning: Trends, Benefits and Risks of Education Digital Transformation". IMS2017, June 2124, 2017, Saint Petersburg, Russian Federation, 2017 Copyright is held by the owner/author(s). Publication rights licensed to ACM. https://doi.org/10.1145/3143699.3143741

[26] Supparang Ruangvanic, Prachyanun Nilsook, "Students' Usage of Mobile Learning on Information Technology and Communication Subject for Grade 9 Students". ICDEL '18, May 26-28, 2018, Beijing, China ( 2018 ACM. https://doi.org/10.1145/3231848.3231878

[27] Michael M. Grant, "Difficulties in defining mobile learning: analysis, design characteristics, and implications". Education Tech Research Dev (2019) 67:361-388, Association for Educational Communications and Technology 2019, Springer. https://doi.org/10.1007/s11423018-09641-4

[28] Luna, J.M., Castro, C., Romero, C.: MDM tool: a data mining framework integrated into moodle. Comput. Appl. Eng. Educ. 25(1), 90-102 (2017) https://doi.org/10.1002/cae.21782

[29] Arif BAKLA, "A CRITICAL OVERVIEW OF INTERNET OF THINGS IN EDUCATION". Mehmet Akif Ersoy Üniversitesi Eğitim Fakültesi Dergisi e-ISSN: 21465983 Y1l: 2019 Say1: 49 Sayfa: 302-327. https://doi.org/10.21764/maeuefd.543883

[30] Rima Shishakly, "Smartphones enhance the management of learning processes in Higher Education: A case study in Ajman University, United Arab Emirates". IC4E 2019, January 10-13, 2019, Tokyo, Japan (C) ACM. https://doi.org/10.1145/3306500.3306513

\section{Authors}

Hosam F. El-Sofany currently works at the Department of Computer Science and Management at King Khalid University. His current project is 'A Cloud-based System for Medical Diagnosis using Fuzzy Logic Concepts'. Email: helsofany@kku. edu.sa

Nahla El-Haggar works at Community College, Imam Abdulrahman Bin Faisal University, Dammam, Saudi Arabia. Email: naelhaggar@iau.edu.sa

Article submitted 2020- 01-10. Resubmitted 2020-02-19. Final acceptance 2020-02-20. Final version published as submitted by the authors. 